\title{
Adjustment of Cost 231 Hata Path Model For Cellular Transmission in Rivers State
}

\author{
B.O.H Akinwole ${ }^{1}$, Esobinenwu C.S ${ }^{2}$ \\ ${ }^{I}$ (Department of Electrical/Electronic Engineering, University of Port Harcourt Port Harcourt, Nigeria)
}

\begin{abstract}
Path loss prediction models are essential tools in radio network planning for cellular transmission as they are used for received signal strength estimation, link budget design and analysis, cell size estimation, and interference optimization. This paper presents empirical path loss models developed for WCDMA microcells operating at $2100 \mathrm{MHz}$ on live radio Globacom Node Bs in the urban, suburban, and rural areas in Rivers state. The performance of COST 231 Hata model, Stanford University Interim, and Electronic Communication committee 33 were compared with measured field data. COST 231 Hata model gave a better prediction but with high RMSE and SD which are outside the acceptable value for a good radio signal propagation. COST 231 Hata model was for adjustment based on Linear Least Square Algorithm (LLSA). After adjustment and simulations, the adjusted COST 231 Hata model gave better predictions with minimum MSE and SD that are within the acceptable values. The adjusted COST 231 Hata can accurately be used for predicting the radio characteristic of Rivers State.
\end{abstract}

Keywords: Path loss prediction, cellular transmission, COST -231 Hata model, Mean Square Error, Standard Deviation, Linear Least Square Algorithm.

\section{Introduction}

As the demand to meet the heterogeneous service requirements of different applications for cellular wireless services increases, the needs for high quality and high capacity network become extremely important.

For more coverage design of modern cellular networks the signal strength measurements must be taken into consideration. Path loss models are mathematical tools used daily by the Engineers and Network planners for proper determination of the received signal strength at certain location from the Node B. Path loss is defined as the difference in $\mathrm{dB}$ between effective transmitted power and the received power [1]. There are lots of different path loss models described by various research experiments. It is important to know that the result of each experiment depends on the environmental conditions under which an experiment was carried out. Each model can be useful for some specific environments, terrain and climate. Therefore, there is no general algorithm that is globally accepted as the best propagation model. Choosing an accurate and realistic path loss model for signal predictions, depends on the fit between the parameters available for the area concerned and parameters required by the model. Therefore, Predictions must be verified by measurements taken from the field survey and the model adjusted accordingly. In this paper, a classical propagation model is adjusted in agreement with field measured data in order to generate predictions with minimal error. The paper is organized as follows. Section 2, presents an overview of the four common existing path loss model considered. The procedure and tools used for obtaining the measured data are described in section 3. Section 4 presents the data obtained from field measurements. The measured results are compared with the results from the three existing models considered in section 5. Model adjustments are presented in section 6.

\subsection{Log-normal Shadowing Path loss model}

\section{Existing Path loss models}

This model describes the random shadowing effects that occur over a large number of measurement locations with the equal separation distance between the transmitter and the receiver. The path loss model is given as [3]:

$$
\mathrm{L}(\mathrm{dB})=\mathrm{L}(\mathrm{d})+10 \mathrm{rlog}\left(\frac{\mathrm{d}}{\mathrm{do}}\right)+\mathrm{X} \sigma
$$

$\mathrm{L}(\mathrm{dB})$ is random and log-normally distributed about the distance Where, $\mathrm{X} \sigma$ is a zero mean Gaussian distributed random variable (in $\mathrm{dB}$ ).

\subsection{COST 231 Hata model}

COST 231 Hata model is an empirical model used for calculating path loss in cellular mobile system. This model is an extension of the Okumura-Hata model designed to cover frequency ranges from $1700 \mathrm{Mz}$ to $2300 \mathrm{MHz}$ with receiving antenna heights up to $10 \mathrm{~m}$ and transmitting antenna heights of $30 \mathrm{~m}-200 \mathrm{~m}$. COST 231 
Hata model contains correction factors for urban, suburban, and rural areas. The equation for COST 231 Hata path loss model is expressed as [3]:

$$
\mathrm{L}_{\text {CosT231Hata }}=46.3+33.9 \log _{10}\left(\mathrm{f}_{\mathrm{c}}\right)-13.82 \log _{10} \quad\left(\mathrm{~h}_{\mathrm{t}}\right)-\mathrm{a}\left(\mathrm{h}_{m}\right)+\left[44.9-\quad 6.55 \log _{10}\left(\mathrm{~h}_{\mathrm{t}}\right)\right] \log _{10}(d)+C_{m}
$$

Where, $d$ is the link distance in Kilometres, $f_{c}$ is the frequency in $\mathrm{MHz}, \mathrm{h}_{\mathrm{t}}$ is the effective height of the transmitting antenna in meters, $h_{r}$ is the effective height of the receiving antenna in meters, $C_{m}$ is the correction factor and is defined $0 \mathrm{~dB}$ for rural or suburban and $3 \mathrm{~dB}$ for urban area.

For rural or suburban area,

Correction factor for receiver antenna height:

$\mathrm{a}\left(\mathrm{h}_{\mathrm{m}}\right)=\left(1.11 * \log _{10} \mathrm{f}_{\mathrm{c}}-0.7\right) \mathrm{h}_{\mathrm{t}}-\left(1.5 * \log _{10} \mathrm{f}_{\mathrm{c}}-0.8\right)$

For Urban:

$\mathrm{a}\left(\mathrm{h}_{\mathrm{m}}\right)=3.2\left(\log _{10}\left(11.75 \mathrm{~h}_{\mathrm{m}}\right)\right)^{2}-4.79$

\subsection{Stanford University Interim (Sui) Model}

The Stanford University Interim was developed by the working group of Institute of Electrical Electronic Engineers (IEEE 802.16) for path loss prediction in all three macro-cellular environments. The model is formulated to operate based on an operating frequency above $1900 \mathrm{MHz}$ and a cell radius of $0.1 \mathrm{~km}$ to $8 \mathrm{~km}$, base station antenna height $10 \mathrm{~m}$ to $80 \mathrm{~m}$, and receiver antenna height of $1 \mathrm{~m}$ to $10 \mathrm{~m}$. This model is divided into three categories of terrains namely A, B, C. The terrain category A is associated with maximum path loss, and densely populated region. Moderate path loss is captured in terrain category B. The terrain category $\mathrm{C}$ is associated with minimum path loss and flat terrain with light tree densities.

The basic path loss formula for SUI model is expressed as [3]:

$\mathrm{L}_{\mathrm{SUI}}=\mathrm{A}+10 r \log _{10}\left(\mathrm{~d} / \mathrm{d}_{\mathrm{o}}\right)+\mathrm{X}_{\mathrm{f}}+\mathrm{X}_{\mathrm{h}}+\mathrm{S}(3)$

For $\mathrm{d}>\mathrm{d}_{\mathrm{o}}$, and $\mathrm{d}_{\mathrm{o}}=0.1 \mathrm{Km}$

The parameter for Free space attenuation, $A$ is expressed as:

$\mathrm{A}=20 \log _{10}\left(4 \pi d_{0} / \lambda\right)$

$r$ is the path loss exponent, $h_{t}$ is the effective base station height, the constants used for $a, b$, and $c$ are given in Table 1.

Table1: Numerical values for the SUI Model Parameters

\begin{tabular}{|l|l|l|l|}
\hline Model parameter & Terrain A & Terrain B & Terrain C \\
\hline $\mathrm{A}$ & 4.6 & 4.0 & 3.6 \\
\hline $\mathrm{b}\left(\mathrm{m}^{-1}\right)$ & 0.0075 & 0.0065 & 0.005 \\
\hline $\mathrm{c}(\mathrm{m})$ & 12.6 & 17.1 & 20 \\
\hline
\end{tabular}

$\mathrm{X}_{\mathrm{f}}$ is the frequency correction factor: $\mathrm{X}_{\mathrm{f}}=6.0 \log _{10}\left(\frac{\mathrm{f}_{\mathrm{c}}}{2000}\right)$

$\mathrm{X}_{\mathrm{h}}$ is the correction factor for receiving antenna height is defined as:

$X_{h}=\left\{\begin{array}{l}-10.8 \log 10\left(\frac{H_{R}}{2000}\right), \text { for categories A,B and B } \\ -20 \log 10\left(\frac{H_{R}}{2000}\right) \text { for terrain category C }\end{array}\right.$

$s$ is the correction for shadow fading factor, and is defined between $8.2 \mathrm{~dB}$ and $10.6 \mathrm{~dB}$.

where $\mathrm{f}_{\mathrm{c}}$ is the operating frequency in $\mathrm{MHz}$, and $\mathrm{h}_{\mathrm{r}}$ is the receiver antenna height in meters.

\subsection{ECC-33 model}

The Electronic Communication Committee 33 model was developed by Electronic Communication Committee. This model is designed to predict path loss at higher frequency greater than $3 \mathrm{GHz}$. In this model, path loss is given by [4]:

$\mathrm{L}_{\mathrm{ECC}-33}=\mathrm{A}_{\mathrm{fs}}+\mathrm{A}_{\mathrm{bm}}-\mathrm{G}_{\mathrm{t}}-\mathrm{G}_{\mathrm{r}}(4)$

where,

$A_{\mathrm{fs}}$ is the free space attenuation $(\mathrm{dB}), \mathrm{A}_{\mathrm{bm}}$ is the basic median path loss $(\mathrm{dB}), \mathrm{G}_{\mathrm{t}}$ is the transmitter antenna height gain factor, $G_{r}$ is the receiver antenna height gain factor.

where, the free space attenuation:

$\mathrm{A}_{\mathrm{fs}}=92.4+20 \log _{10}(\mathrm{~d})+20 \log _{10}\left(\mathrm{f}_{\mathrm{c}}\right)$,

Basic median path loss: 
$A_{b m}=20.41+9.83 \log _{10}(d)+7.894 \log _{10}\left(f_{c}\right)+9.56\left[\log _{10}\left(f_{c}\right)\right]^{2}$,

Transmitter antenna height gain factor:

$\mathrm{G}_{\mathrm{t}}=\log _{10}\left(\mathrm{~h}_{\mathrm{t}} / 200\right)\left\{13.958+5.8\left[\log _{10}\left(\mathrm{~h}_{\mathrm{r}}\right)\right]\right\}^{2}$

The receiver antenna height gain factor, Gr for

medium cities is expressed as:

$\mathrm{G}_{\mathrm{r}}=\left[42.57+13.7 \log _{10}\left(\mathrm{f}_{\mathrm{c}}\right)\right]\left[\log _{10}\left(\mathrm{~h}_{\mathrm{r}}\right)-0.585\right]$

\section{Data collection method and procedure}

To predict path loss model for cellular transmission, practical data from the field measurement are required. Downlink data were collected at various distances on live radio Globacomm WCDMA Node Bs at transmits frequency of $2100 \mathrm{MHz}$. A drive test tools used for collecting data include a laptop equipped with drive test Ericsson software, Map info software (professional version 8.0), a communication Network Analyser software (ACTIX analyser 4.05), Garmin GPS 12XL receiver, Two C702 Sony Ericsson TEMS phone for idle and dedicated mode, an inverter and extension board. The test was carried out on three different locations in Rivers State:

Rumukoro, with co-ordinate $\left(4^{\circ} 48^{\prime} 522^{\prime \prime} 7^{\circ} 12^{\prime} 6 \mathrm{E}^{\prime \prime}\right)$ is selected as urban area, Finima, Bonny Island with co-ordinate $\left(4^{\circ} 26^{\prime} 12.8^{\prime \prime} \mathrm{N} 7^{\circ} 10^{\prime} 25.5^{\prime \prime} \mathrm{E}\right)$ selected as sub-urban area, and Borokiri (Creek road) coordinates $\left(4^{0} 45^{\prime} 50.5^{\prime \prime} \mathrm{N} 7^{\circ} 1{ }^{\prime} 26.4^{\prime \prime} \mathrm{E}\right)$ selected as rural area.

The two Sony Ericsson UEs, GPS receiver and the Dongle probe were coupled to a laptop placed in a car. The laptop was powered on in order to launch TEMS investigation software. All the equipment were connected and detected on TEMS interface. The routes and the Node Bs were identified before setting out for the drive test. The car was driven around through a predefined route in the direction of the Active Sector (AS) of the directional antenna away from the site until it got to the coverage border. The car was driven at an average speed of $30 \mathrm{Km} / \mathrm{h}$. Two modes of configurations for the handsets were used for the monitored software during this drive-test. These were the idle and dedicated modes. $\mathrm{M}_{1}$ was set at idle mode and $\mathrm{M}_{2}$ was set at dedicated mode. $\mathrm{M}_{2}$ was preset automatically to make a continuous call to a fixed destination number. The received signal power is measured using Ericsson handset and transferred to the TEMS log file in the laptop. The GPS receiver gave the location and distance from the Node B synchronously with the received power level reading and was recorded on the laptop. The experimental data were taken at distances ranging from 100meters to 1 kilometer. Measurements were carried out between and October and November, 2012.

Table 2: Simulation Parameters.

\begin{tabular}{|l|l|}
\hline Parameters & Values \\
\hline Antenna type & S-wave 0809-65-15DV14 \\
\hline Operating frequency & $2100 \mathrm{MHz}$ \\
\hline Node B transmitter & $43 \mathrm{dBm}$ in urban, \\
& $46 \mathrm{dBm}$ in sub-urban, 48dBm in rural. \\
\hline Node B antenna height & $30 \mathrm{~m}$ in urban, 34m in suburban, \\
& $38 \mathrm{~m}$ in rural \\
\hline UE antenna height & $1.5 \mathrm{~m}$ \\
\hline Node B antenna gain & $18 \mathrm{~dB}$ \\
\hline UE antenna gain & $0 \mathrm{~dB}$ \\
\hline Connector loss & $2 \mathrm{~dB}$ \\
\hline Cable loss & $1.5 \mathrm{~dB}$ \\
\hline Duplexer loss & $1.5 \mathrm{~dB}$ \\
\hline Body loss & $3 \mathrm{~dB}$ \\
\hline
\end{tabular}

\section{Data analysis}

The field measurement and the corresponding path loss values are given in Tables (3)-(5). $\mathrm{L}(\mathrm{dB})=10 \log _{10} \frac{P_{t}}{P_{r}}$

Table 3: Measured path loss for urban area

\begin{tabular}{|l|l|l|}
\hline Distance between the Node B and the UE, $\mathbf{d}(\mathbf{K m})$ & Mean received level $(\mathbf{d B m})$ & Measured Pat Loss, $(\mathbf{d B})$ \\
\hline 0.10 & -69 & 115 \\
\hline 0.20 & -74 & 120 \\
\hline 0.30 & -79 & 125 \\
\hline 0.40 & -80 & 126 \\
\hline 0.50 & -82 & 128 \\
\hline 0.60 & -85 & 131 \\
\hline 70 & -89 & 135 \\
\hline 0.80 & -93 & 139 \\
\hline 0.90 & -97 & 143 \\
\hline 1.00 & -99 & 145 \\
\hline
\end{tabular}


Table 4: Measured Path Loss for Suburban area.

\begin{tabular}{|l|l|l|}
\hline $\begin{array}{l}\text { Distance between the } \\
\text { Node B and the UE, d } \\
(\mathbf{K m})\end{array}$ & $\begin{array}{l}\text { Mean } \\
\text { Received } \\
\text { Level } \\
(\mathbf{d B m})\end{array}$ & $\begin{array}{l}\text { Measured Path Loss, } \\
(\mathbf{d B})\end{array}$ \\
\hline 0.10 & -62 & 110 \\
\hline 0.20 & -68 & 116 \\
\hline 0.30 & -71 & 119 \\
\hline 0.40 & -75 & 123 \\
\hline 0.50 & -77 & 125 \\
\hline 0.60 & -81 & 129 \\
\hline 0.70 & -83 & 131 \\
\hline 0.80 & -85 & 133 \\
\hline 0.90 & -87 & 135 \\
\hline 1.00 & -89 & 137 \\
\hline
\end{tabular}

Table 5: Measured Path Loss for Rural area

\begin{tabular}{|l|l|l|}
\hline $\begin{array}{l}\text { Distance between } \\
\text { the Node B and the } \\
\text { UE, d (Km) }\end{array}$ & $\begin{array}{l}\text { Mean Received } \\
\text { Level }(\mathbf{d B m})\end{array}$ & $\begin{array}{l}\text { Measured Poss, (dB) } \\
\text { Los }\end{array}$ \\
\hline 0.10 & -60 & 110 \\
\hline 0.20 & -62 & 112 \\
\hline 0.30 & -67 & 117 \\
\hline 0.40 & -71 & 121 \\
\hline 0.50 & -74 & 124 \\
\hline 0.60 & -77 & 127 \\
\hline 0.70 & -79 & 129 \\
\hline 0.80 & -81 & 131 \\
\hline 0.90 & -83 & 133 \\
\hline 1.00 & -85 & 135 \\
\hline
\end{tabular}

The values of the reference path loss and the path loss exponent for urban, suburban and rural areas are obtained from the measured values given in Tables (3) - (5) using linear regression [5]; Excel program. Considering other losses, the resultant Path Loss model for field measurement estimated for the three locations (urban, suburban, and rural areas) is expressed as:

$$
\mathrm{L}_{\text {estimated }}(\mathrm{dB})=\mathrm{L}(\mathrm{d})+10 * \mathrm{r} * \log _{10}\left(\frac{d}{d_{o}}\right)+X_{\sigma}+\left(G_{T}+G_{R}\right)-\left(L_{R}+L_{T}\right)
$$

\section{Comparison of measured path loss with existing path loss model}

The path loss values for the three existing models investigated are estimated using equations (2)(5).The results were compare with the path loss from the field measurements for the three locations and the results given by Figs (1)-(3) .It is necessary to know that ECC-33 model is not applicable to rural environment.

\section{Result and analysis}

From the above plots, Figs (1)- (3) showed that ECC-33 model overestimated the measured path loss and have the highest predictions for the three environments, followed by SUI model. COST 231 Hata model under estimated measured path loss with high prediction values (Table 6). The comparisons were based on MSE and SD between the measured path loss and predictions by ECC-33, SUI, COST 231 Hata, models, and they are expressed as [6]:

$$
\begin{aligned}
& \text { MSE }=\sqrt{\frac{\sum_{l=1}^{\mathrm{n}}\left(\mathrm{P}_{\mathrm{m}}-\mathrm{P}_{\mathrm{r}}\right)^{2}}{\mathrm{n}-1}} \\
& \sigma=\sqrt{\frac{\left(\sum_{i=1}^{n}\left(\mathrm{P}_{\mathrm{m}}-\mathrm{P}_{\mathrm{r}}\right)^{2}\right.}{n}}
\end{aligned}
$$

Where, $P_{m}$ Where, $P_{m}=$ the measured path loss $(d B), P_{r}$ is the predicted path loss $(d B)$, and $n$ is the number of measured data points. The results are tabulated in Table (6). 
Table (6): Statistical evaluation of MSE and SD for COST 231 Hata, SUI and ECC-33 models before model adjustment

\begin{tabular}{|l|l|l|l|l|l|}
\hline $\begin{array}{l}\text { Verificati } \\
\text { on items }\end{array}$ & \multicolumn{2}{|l|}{$\begin{array}{l}\text { COST 231 Hata } \\
\text { model }\end{array}$} & \multicolumn{2}{l|}{ SUI model } & $\begin{array}{l}\text { ECC-33 } \\
\text { model }\end{array}$ \\
\hline & MSE & SD & MSE & SD & MSE \\
\hline Urban & 20.440 & 19.391 & 37.185 & 35.277 & 162.646 \\
\hline Suburban & 17.156 & 16.276 & 36.284 & 38.247 & 169.379 \\
\hline Rural & 14.759 & 14.002 & 36.786 & 38.776 & 118.751 \\
\hline
\end{tabular}

The acceptable limit for good signal propagation is 6dB [6]. COST 231 Hata model has the least MSE and SD for the three environments and was selected for adjustment using linear iterative method based on Least Square Algorithm.

\section{Model adjustments}

According to [7], a general radio path loss model based on COST 231 Hata model is defined as: $\mathrm{L}(\mathrm{cos})=\mathrm{K}_{1}+\mathrm{K}_{2} \log _{10} \mathrm{~d}+\mathrm{K}_{3} \log _{10} \mathrm{~h}_{\mathrm{t}}+\mathrm{K}_{4} \log _{10} \mathrm{~h}_{\mathrm{t}} * \log _{10} \mathrm{~d}-\mathrm{K}_{5} \log _{10} \mathrm{f}-\mathrm{a}(\mathrm{hm})$,

where $K_{1}-K_{5}$ are model adjustable parameters for the model, $d$ is the link distance, $f_{c}$ is the frequency in $\mathrm{MHz}, \mathrm{h}_{\mathrm{t}}$ is the effective height of the transmitting antenna in meters, $h_{r}$ is the effective height of the receiving antenna in meters.

The parameters $\left(\mathrm{K}_{1}\right.$ and $\left.\mathrm{K}_{2}\right)$ of the model are adjusted using Linear Least Square Algorithm .The accuracy of the proposed COST 231 Hata models in different environments depend on the proper adjustment of these parameters and the results are presented in Table (7).

The path loss formula for proposed adjusted COST 231 Hata model is given as: L(adj)

$=\mathrm{K}_{1}+\mathrm{K}_{2} \log _{10} \mathrm{~d}+\mathrm{K}_{3} \log _{10} \mathrm{~h}_{\mathrm{t}}+\mathrm{K}_{4} \log _{10} \mathrm{~h}_{\mathrm{t}} * \log _{10} \mathrm{~d}-\mathrm{K}_{5} \log _{10} \mathrm{f}-\mathrm{a}\left(\mathrm{h}_{\mathrm{m}}\right)+\mathrm{C}_{1}+\mathrm{C}_{2} \log _{10} \mathrm{~d}$

$=\left(\mathrm{K}_{1}+\mathrm{C}_{1}\right)+\left(\mathrm{K}_{2}+\mathrm{C}_{2}\right) \log 10 \mathrm{~d}+\mathrm{K}_{3} \log _{10} \mathrm{~h}_{\mathrm{t}}+$

$\mathrm{K}_{4} \log _{10} \mathrm{~h}_{\mathrm{t}} * \log _{10} \mathrm{~d}-\mathrm{K}_{5} \log _{10} \mathrm{f}-\mathrm{a}\left(\mathrm{h}_{\mathrm{m}}\right)$

where $K_{1}+C_{1}$ is the $K_{1}$ after model adjustment ,

$\mathrm{K}_{2}+\mathrm{C}_{2}$ is the $\mathrm{K}_{2}$ after model adjustment, while other parameters remain constant.

Table (7): Parameters of COST 231 Hata model after adjustment

\begin{tabular}{|l|l|l|l|l|l|l|}
\hline Parameter & \multicolumn{2}{|l|}{ Urban } & \multicolumn{2}{l|}{ Sub urban } & Rural \\
\hline $\begin{array}{l}\text { Before } \\
\text { adjustment }\end{array}$ & $\begin{array}{l}\text { After } \\
\text { adjustme } \\
\text { nt }\end{array}$ & $\begin{array}{l}\text { Before } \\
\text { adjust } \\
\text { ment }\end{array}$ & $\begin{array}{l}\text { After } \\
\text { adjust } \\
\text { ment }\end{array}$ & $\begin{array}{l}\text { Before } \\
\text { adjust } \\
\text { ment }\end{array}$ & $\begin{array}{l}\text { After } \\
\text { adjustme } \\
\text { nt }\end{array}$ \\
\hline C1 & 17.269 & & 13.51 & & 11.098 \\
\hline C2 & & -5.923 & & -7.57 & & -7.853 \\
\hline K1 & $\begin{array}{l}46 . \\
3\end{array}$ & 63.57 & 46.3 & 59.81 & 46.3 & 57.40 \\
\hline K2 & $\begin{array}{l}44 . \\
9\end{array}$ & 3897 & 44.9 & 37.33 & 44.9 & 37.05 \\
\hline K3 & & & & & & \\
\hline K4 & -13.82 & -6.55 & & & \\
\hline K5 & 33.9 & & & \\
\hline
\end{tabular}

The adjusted COST 231 Hata model is validated by applying it to the experiment areas in order to obtain accurate predictions closer to the field measurements for these areas. The performance of the adjusted COST 231 Hata model is compared with the classical COST 231 Hata model and the measured path loss by comparing the predicted path loss values with the measured values using MSE and SD. The result is shown in Table (8).

Table (8): Statistical verification of adjusted model

\begin{tabular}{|l|l|l|l|}
\hline $\begin{array}{l}\text { Verification } \\
\text { items }\end{array}$ & Urban & Suburban & Rural \\
\hline MSE & 3.1601 & 0.124 & 0.123 \\
\hline SD & 2.9979 & 0.118 & 0.116 \\
\hline
\end{tabular}

The results in Table (8), show the MSE and SD for the proposed model. The proposed adjusted COST 231 Hata models showed better agreement with the measured values, since its MSE and SD are within the acceptable value. Figs (4)-(6) shows the comparison between the proposed adjusted COST 231 Hata model and classical COST 231 Hata model. 


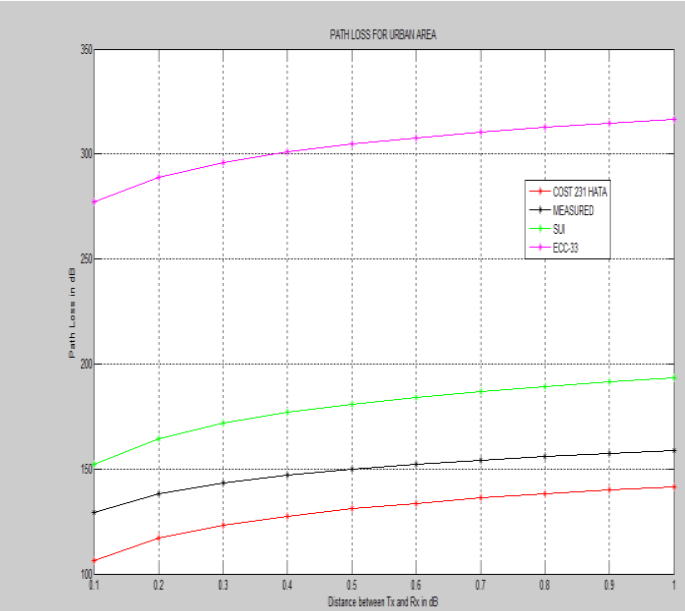

Figure 1: Comparison of path loss models with the measurement from urban area

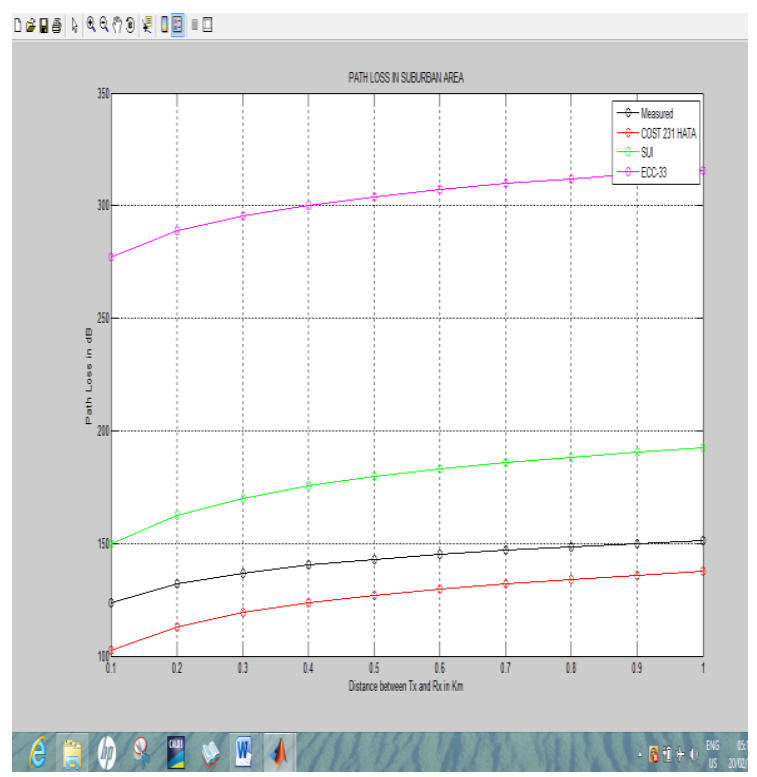

Figure 2: Comparison of path loss models with measurement from suburban area

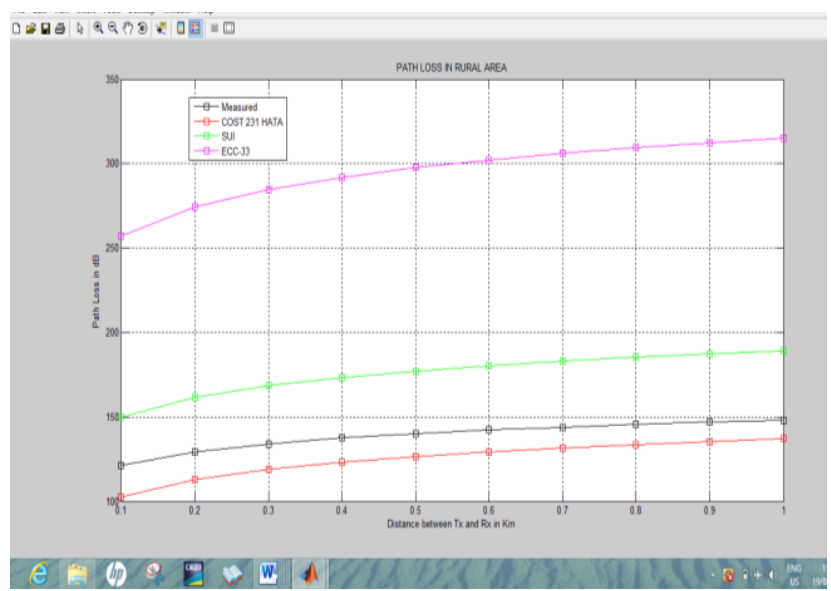

Figure 3: Comparison of path loss models with measurement from rural area 


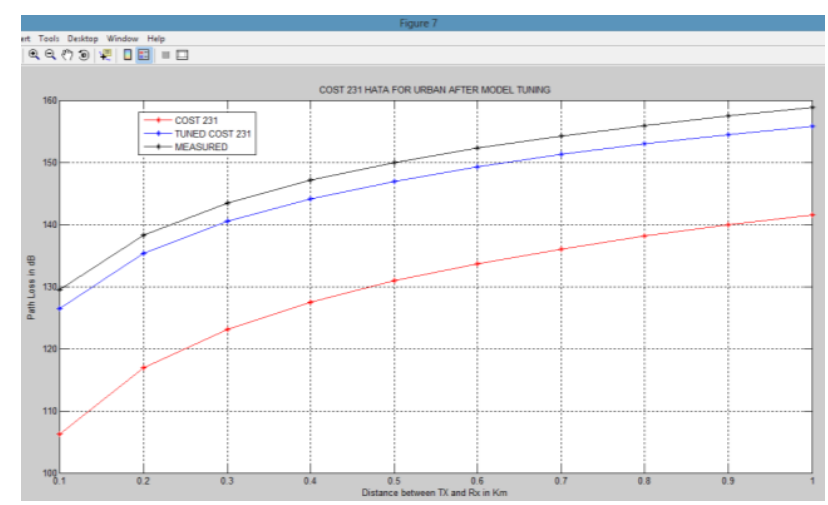

Figure 4: Path loss comparison of Cost 231 model before and after model adjustment for urban area.

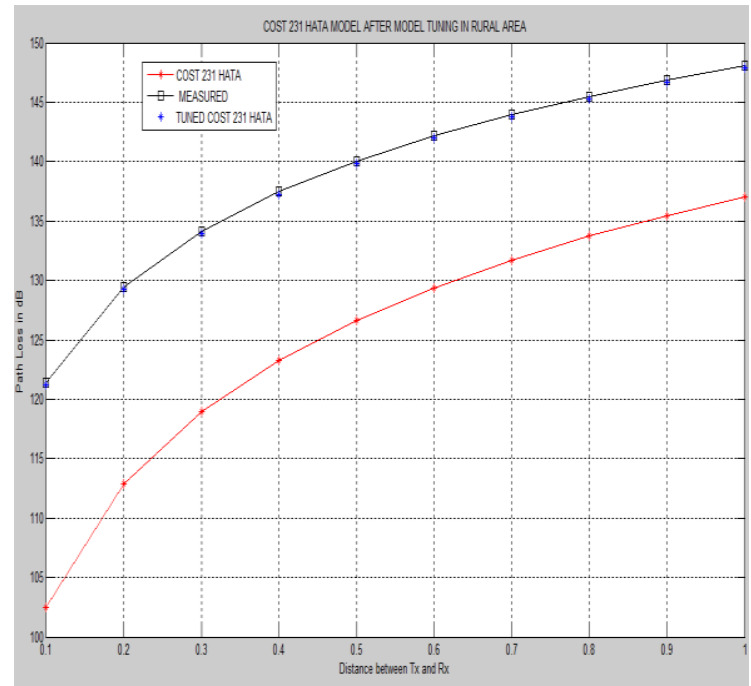

Figure 5: Path loss comparison of Cost 231 model before and after model adjustment for suburban area

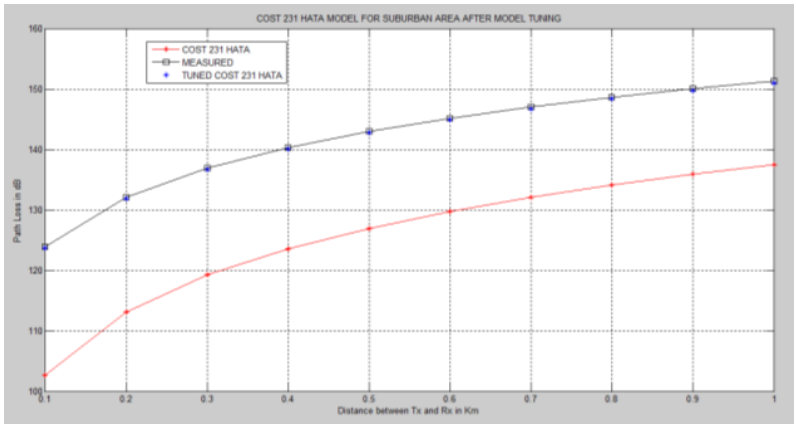

Figure 6: Path loss comparison of Cost 231 model before and after model adjustment for rural area

\section{Conclusions}

This paper presents a statistically adjusted COST 231 Hata model for link budget design and analysis using a simple Linear -iterative Least Square algorithm based on existing path loss model. The outdoor measurements of the received signal power have been collected through drive tests in urban, suburban, and rural areas in Rivers state for comparison with the existing path loss models. The Results of the plots between the proposed adjusted COST 231 Hata model and the measured path loss showed better performance of the adjusted model in these environments. The adjusted model was found suited in these environments, and can be used to predict the signal strength of mobile phone. COST 231 Hata model appears to strike the balance between simplicity and accuracy. But with the adjusted proposed model, Network provider can improve their service for better capacity and better user satisfactions. 


\section{References}

[1]. Rappaport, T.S, Wireless Communications, Second Edition, Pearson Publication, India, , pp 1392005,

[2]. Rakesh N., Srivasta S.K, An Investigation on Propagation Path Loss in Urban Environments for Various Models at Transmitter Antenna Height of 5om and Receiver Antenna heights of $10 \mathrm{~m}, 15 \mathrm{~m}$ and $20 \mathrm{~m}$ International journal of research and reviews in Computer science, vol 3 ,no 4, 2012, pp 1761-1767,

[3]. Bruno S.L Marcio R, Gervasio P, "Comparision Between Known Propagation Models Using Least Squares Tuning Algorithm on $5.8 \mathrm{GHz}$ in Amazon Region Cities" Journal of Microwaves, Optoelectronics and Electromagnetic Applications, Vol.10, No,1, 2011,pp 106-113

[4]. Nwaogazie I. L. "Probability Statistics for Science and Engineering Parctice 2006, pp 114-120.

[5]. Nadir Z, Muhammed I. A "Pathloss Determination using Okumura - Hata Model And Cubic regression for Missing Data for Oman", Proceedings of the International Multi Conference of Engineers and Computer Scientists , IAEN-ICCSA 2010,Hong Kong 20 Vol II1, pp 804-807.

[6]. Luo Shuwan, Yang Geng, Propagation model tuning of TD-SCDMA, Guangdong Communication Technology, Guangdong Telecommunication Press, pp 37-41,2002

[7]. M.Yang, W.Shi, A Linear least Square Method of propagation model tuning for 3G Radio Network Planning, Fourth International Conference on National Computation ICNC,Jianan,pp150-154 